MaPan : Jurnal Matematika dan Pembelajaran

p-ISSN: 2354-6883 ; e-ISSN: 2581-172X

Volume 7, No 2, December 2019 (291-306)

DOI: https://doi.org/10.24252/mapan.2019v7n2a9

\title{
EFEKTIVITAS MEDIA ADAMMATH (APLIKASI DAM MATEMATIKA) TERHADAP PEMAHAMAN KONSEP MATEMATIS SISWA MATERI PERSAMAAN GARIS LURUS
}

\author{
Muchamad Adam Kurniyawan'1), Ciptianingsari Ayu Vitantri²), \\ Dian Novita Rohmatin ${ }^{3)}$ \\ 1,2,3Universitas Pesantren Tinggi Darul Ulum Jombang \\ 1,2,3Kompleks PP Darul Ulum Peterongan Jombang, Peterongan, Jombang \\ E-mail: adamkurniawan695@gmail.com ${ }^{11}$, ciptianingsariayu@mipa.unipdu.ac.id ${ }^{2}$, \\ diannovita711@gmail.com ${ }^{3}$ )
}

Submitted: 14-09-2019, Revised: 28-09-2019, Accepted: 28-11-2019

\begin{abstract}
Abstrak:
Media pembelajaran berbentuk permainan sangatlah baik untuk membangun pemahaman konsep siswa karena media diberikan secara detail dan mudah dipahami oleh siswa. Penelitian ini bertujuan untuk mengetahui keefektifan media ADAMMATH (Aplikasi DAM Matematika) terhadap kemampuan pemahaman konsep matematis siswa pada pokok bahasan persamaan garis lurus. Metode penelitian yang digunakan adalah model penelitian deskriptif. Instrumen dalam penelitian ini adalah lembar angket respons siswa dan lembar pengamatan aktivitas siswa. Subjek dalam penelitian ini adalah siswa kelas VIII MTs Umar Zahid Perak Jombang berjumlah 28 siswa. Jenis data yang diperoleh dalam penelitian ini adalah data kualitatif dan kuantitatif. Hasil uji coba keefektifan dilihat dari angket respons siswa memenuhi kategori baik yaitu 3,01 $\left(S_{m} \geq 2,5\right)$ dan lembar pengamatan aktivitas siswa untuk melihat kemampuan pemahaman konsep matematis siswa menggunakan media ADAMMATH memenuhi kriteria baik yaitu 0,62 $\left(S_{m} \geq 0,50\right)$. Hasil penelitian ini menunjukkan bahwa media ADAMMATH terbukti efektif terhadap pemahaman konsep matematis siswa pada materi persamaan garis lurus.
\end{abstract}

Kata Kunci: Efektivitas, Media ADAMMATH, Pemahaman Konsep Matematis, Persamaan Garis Lurus

THE EFFECTIVENESS OF THE ADAMMATH MEDIA (DAM MATHEMATICS APPLICATION) ON STUDENTS' UNDERSTANDING OF MATHEMATICAL CONCEPTS IN STRAIGHT LINE EQUATION MATERIAL

\begin{abstract}
:
Games as learning media are very good for building students' understanding of concepts because of presented in detail and easily captured by students. This research aimed to determine the effectiveness of ADAMMATH media (Mathematical DAM Application) to understand students' mathematical concepts on the subject matter of valid, effective and practical Straight Line Equations. This research used descriptive approach. The instruments used were questionnaire and observation sheets. The subject in this research was the 8th grade students of MTs Umar Zahid Perak Jombang which consisted of 28 students. The type of data
\end{abstract}


obtained in this study were qualitative and quantitative data. The findings from the questionnaire was categorized good with $3.01\left(S_{m} \geq 2.5\right)$ and from the observation sheet of the students' activities to know the ability of understanding mathematical concepts by applying ADAMMATH media was also good criteria, $0.62\left(S_{m} \geq 0.50\right)$. The result of this research indicated that ADAMMATH was effective on the students' understanding of mathematical concepts in the material Straight Line Equations.

Keywords: Effectivenes, ADAMMATH Media, Mathematical Concept Understanding, Straight Line Equations

How to Cite: Kurniyawan M. A., Vitantri, C. A., \& Rohmatin, D. N. (2019). Efektivitas media ADAMMATH (Aplikasi DAM Matematika) terhadap pemahaman konsep matematis siswa materi persamaan garis lurus. MaPan: Jurnal Matematika dan Pembelajaran, 7(2), 291-306.

\section{PENDAHULUAN}

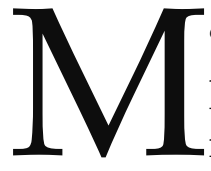
atematika sebagai dasar dari segala bidang ilmu, sehingga sangat penting untuk dipelajari oleh setiap individu. Sudiono (2017) mengatakan bahwa matematika dikenal sebagai ilmu yang bersifat abstrak yang dapat melatih kemampuan kritis, logis, analitis dan sistematis. Hal ini telah melahirkan asumsi bagi tiap individu bahwa pelajaran matematika adalah pelajaran yang sulit. Sebagaimana yang diungkapkan Astuty (2012) bahwa penyebab kesulitan siswa dalam mempelajari matematika salah satunya adalah sifatnya yang abstrak. Tabach, Arcavi, \& Hershkowitz (2008) menyatakan bahwa siswa pada tingkat SMP taraf berpikirnya masih belum semuanya berpikir abstrak, masih taraf transisi dari berpikir konkrit ke berpikir abstrak. Hal ini menjadi kendala bagi siswa dalam mempelajari matematika dan kendala bagi guru dalam memberikan pelajaran yang bersifat abstrak.

Hasil survey PISA (The Programmefor International Student Assessment) tahun 2015 menunjukkan bahwa kemampuan matematika siswa Indonesia berumur 15 tahun berada di peringkat 63 dengan skor 386 dari 70 negara dengan aspek yang dinilai adalah kemampuan pemahaman konsep, pemecahan masalah, kemampuan penalaran, dan kemampuan komunikasi (OECD, 2015). Hal ini didukung oleh hasil survey TIMSS (Trends In International Mathematics and Science Study) pada tahun 2011 mengemukakan bahwa Indonesia menempati peringkat ke 38 dari 43 negara dalam pembelajaran matematika dengan aspek yang dinilai dalam matematika adalah pengetahuan tentang fakta, prosedur, konsep, penerapan pengetahuan 
dan pemahaman konsep (TIMSS, 2011). Berdasarkan survey PISA dan TIMSS diatas terlihat bahwa kemampuan siswa Indonesia dalam bidang matematika masih rendah salah satunya kemampuan pemahaman konsep. Oleh karena itu perlu adanya strategi pembelajaran matematika, yang mampu melatih kemampuan pemahaman konsep matematis siswa.

Pemahaman konsep matematis merupakan aspek yang sangat penting agar siswa tidak mengalami kesulitan dalam pembelajaran matematika dan pemahaman konsep lebih bermakna jika dibangun oleh siswa sendiri (NCTM, 2000). Kesumawati (2008) mengungkapkan bahwa pemahaman konsep matematis merupakan landasan penting untuk berpikir dalam menyelesaikan permasalahan matematika maupun permasalahan sehari-hari. Lebih lanjut Vitantri (2017) mengungkapkan bahwa pemahaman dan penguasaan yang baik terhadap konsep suatu materi akan membantu peserta didik dalam mencapai setiap tujuan pembelajaran yang diharapkan. Salah satu materi yang membutuhkan pemahaman konsep adalah materi persamaan garis lurus Menurut Tanjungsari \& Soedjoko (2012), pemahaman konsep persamaan garis lurus siswa masih kurang dilihat dari beberapa masalah salah satunya siswa masih merasa kesulitan dalam menggunakan konsep termasuk didalamnya ketidakmampuan untuk mengingat konsep, ketidakmampuan mendeduksi informasi berguna dari suatu konsep dan kurangnya kemampuan memahami (schematicknowledge) yang ditunjukkan dengan kurang lengkap dalam menuliskan rumus. Putra (2016) dalam penelitiannya menyebutkan bahwa salah satu kesulitan siswa pada materi persamaan garis lurus yaitu siswa kesulitan membayangkan sebuah titik pada koordinat kartesius.

Berdasarkan hasil wawancara terhadap siswa kelas VIII di salah satu sekolah menengah pertama di Jombang pada bulan februari 2019 mengenai pembelajaran yang dilakukan guru saat materi persamaan garis lurus diperoleh hasil bahwa siswa merasa bosan dikarenakan guru mengajar materi persamaan garis lurus cenderung menggunakan metode ceramah. Siswa kesulitan dalam memberi contoh dan bukan contoh persamaan garis lurus, siswa kesulitan dalam menggunakan dan memanfatkan prosedur dalam menyelesaikan soal persamaan garis lurus yang diberikan guru. Wawancara juga dilakukan terhadap guru matematika terkait pemahaman konsep siswa pada materi persamaan garis lurus dengan hasil bahwa siswa sulit mengaplikasikan rumus gradien dan persamaan garis lurus yang tepat pada suatu soal yang diberikan guru karena terlalu banyaknya rumus, siswa sulit menguasai materi persamaan garis lurus dikarenakan materi tersebut ada 
kaitannya dengan materi sebelumnya yaitu aljabar, bidang kartesius, dan grafik yang sebelumnya belum dikuasai. Dari pernyataan diatas dapat disimpulkan bahwa pemahaman konsep matematis siswa pada materi persamaan garis lurus masih rendah dilihat dari indikator pemahaman konsep.

Berdasarkan permasalahan yang di alami siswa, maka guru hendaknya mampu memberikan pengalaman-pengalaman untuk membangun atau membentuk konsep-konsep matematika mengenai persamaan garis lurus. Maka dari itu guru dituntut untuk melakukan pembelajaran yang lebih inovatif. Contoh dari pembelajaran inovatif adalah dengan menggunakan media berbentuk permainan dalam proses pembelajaran matematika. Menurut Rahman (2017), salah satu cara yang dapat digunakan untuk menyajikan soal secara menarik adalah melalui permainan. Menurut Priangga (2017), media pembelajaran sangatlah baik untuk membangun pemahaman konsep siswa karena media diberikan secara detail dan mudah dipahami oleh siswa. Penelitian terkait media pembelajaran materi persamaan garis lurus pernah dilakukan oleh Prasetyo \& Prihatnani (2018) dengan menggunakan permainan monopoli dengan nama Monomath (Monopoli Matematika).

Pada penelitian ini peneliti menggunakan media permainan DAM pada materi persamaan garis lurus. Permainan DAM merupakan salah satu permainan yang dapat mendidik karena sangat baik digunakan dalam memfasilitasi pemahaman konsep. Permainan ini mirip dengan catur namun dalam permainan ini tidak terdapat pion raja, pion benteng, pion kuda, dan pion menteri melainkan bidak/pion yang kedudukannya sama (Prastika \& Purnama, 2013). Penelitian terkait permainan DAM dalam pembelajaran pernah dilakukan oleh Hardani (2017) dalam mata pelajaran kimia. Oleh karena itu, peneliti menggunakan media permainan DAM yang terfokus padamatematika materi persamaan garis lurus Penelitian ini bertujuan untuk mengetahui keefektifan media ADAMMATH terhadap kemampuan pemahaman konsep matematis siswa pada materi persamaan garis lurus.

\section{METODE PENELITIAN}

Penelitian ini merupakan penelitian deskriptif dengan tujuan untuk mengetahui efektivitas media ADAMMATH terhadap kemampuan pemahaman konsep matematis siswa pada materi persamaan garis lurus. Subjek penelitian ini adalah siswa kelas VIII MTs Umar Zahid Perak berjumlah 28 siswa. Instrumen dalam penelitian ini berupa lembar angket 
respons siswa dan lembar pengamatan aktivitas siswa. Jenis data yang diperoleh dalam penelitian ini adalah data kualitatif dan kuantitatif. Data kualitatif berupa tanggapan, kritik dan saran yang dituangkan dalam lembar angket respons siswa dan lembar pengamatan aktivitas siswa. Data kuantitatif berupa skor respons siswa dan skor aktivitas siswa. Adapun kisi-kisi angket respons siswa diadaptasi dari (Rahmawati, 2017) sebagai berikut:

Tabel 1. Kisi-Kisi Angket Respons Siswa

\begin{tabular}{cl}
\hline Kriteria & \multicolumn{1}{c}{ Indikator } \\
\hline \multirow{2}{*}{ Kuantitas } & $\begin{array}{l}\text { Media permainan ADAMMATH membuat pembelajaran } \\
\text { matematika menyenangkan }\end{array}$ \\
& $\begin{array}{l}\text { Media permainan ADAMMATH tidak membuat } \\
\text { kebingungan }\end{array}$ \\
& $\begin{array}{l}\text { Media permainan ADAMMATH menambah semangat } \\
\text { belajar }\end{array}$ \\
& Media permainan ADAMMATH memfasilitasi siswa untuk \\
& memahami konsep dalam materi persamaan garis Lurus \\
& Media permainan ADAMMATH lebih disukai daripada \\
& belajar sendiri \\
& Media permainan ADAMMATH membuat kesulitan \\
& Media permainan ADAMMATH menarik \\
& Tampilan media permainan ADAMMATH menarik \\
& Ukuran Media permainan ADAMMATH sudah sesuai \\
& Soal-soal pada media permainan ADAMMATH mudah \\
& dipahami \\
& Peraturan media permainan ADAMMATH mudah \\
& dipahami \\
& Warna media permainan ADAMMATH menarik \\
& Angka dan simbol pada media permainan ADAMMATH \\
& sudah jelas untuk dibaca \\
& Desain papan pada permainan ADAMMATH menarik \\
& Desain pion pada permainan $A D A M M A T H$ menarik \\
\hline
\end{tabular}

Diadaptasi dari (Rahmawati, 2017) 
Adapun data hasil angket respons siswa dianalisis dengan langkahlangkah berikut:

Menjumlah skor setiap siwa

Menghitung skor rata-rata siswa (Sr) dengan rumus:

$$
\mathrm{S}_{\mathrm{r}}=\frac{\mathrm{S}_{\mathrm{t}}}{\sum \text { butir }}
$$

$\mathrm{S}_{\mathrm{r}}=$ Skor rata-rata setiap siswa

$\mathrm{S}_{\mathrm{t}}=$ Skor total setiap siswa

$\sum$ butir $=$ Jumlah butir pernyataan

Menjumlah $\mathrm{S}_{\mathrm{r}}$ semua siswa.

Menghitung rata-rata untuk semua siswa $\left(\mathrm{S}_{\mathrm{m}}\right)$ dengan rumus:

$$
\mathrm{S}_{\mathrm{m}}=\frac{\sum S_{r}}{n}
$$

$\mathrm{S}_{\mathrm{m}}=$ Skor rata-rata semua siswa

$\sum S_{r}=$ Jumlah skor rata-rata setiap siswa

$n=$ Jumlah siswa yang mengisi angket

Membuat kesimpulan dan hasil angket respons siswa dengan kriteria seperti berikut:

Tabel 2. Kriteria Respons Siswa terhadap Media

Kriteria

\begin{tabular}{ll}
\hline $\mathbf{3 , 5 1} \leq \boldsymbol{S}_{\boldsymbol{m}} \leq \mathbf{4 , 0 0}$ & Respons siswa sangat baik \\
$\mathbf{2 , 5 1} \leq S_{\boldsymbol{m}}<\mathbf{3 , 5 1}$ & Respons siswa baik \\
$\mathbf{1 , 5 1} \leq S_{\boldsymbol{m}}<\mathbf{2 , 5 1}$ & Respons siswa cukup baik \\
$\mathbf{0} \leq \boldsymbol{S}_{\boldsymbol{m}}<\mathbf{1 , 5 1}$ & Respons siswa tidak baik \\
\hline
\end{tabular}

Diadopsi dari (Yamasari, 2010)

Sedangkan kisi-kisi lembar pengamatan aktivitas siswa berisi pernyataan-pernyataan yang disusun untuk mengetahui aktivitas siswa tentang media ADAMMATH terhadap kemampuan pemahaman konsep matematis siswa pada materi persamaan garis lurus dan keefektifan media tersebut sesuai kriteria satu putaran pemain. Berikut kisi-kisi lembar pengamatan aktivitas siswa:

Tabel 3. Kisi-Kisi Lembar Pengamatan Aktivitas Siswa

\begin{tabular}{cl}
\hline No & \multicolumn{1}{c}{ Indikator } \\
\hline 1 & Menjalankan pion sesuai aturan \\
2 & Menyebutkan gradien dengan benar \\
3 & Menyelesaikan soal dengan tepat \\
\hline
\end{tabular}

296 | Volume 7, No 2, December 2019 


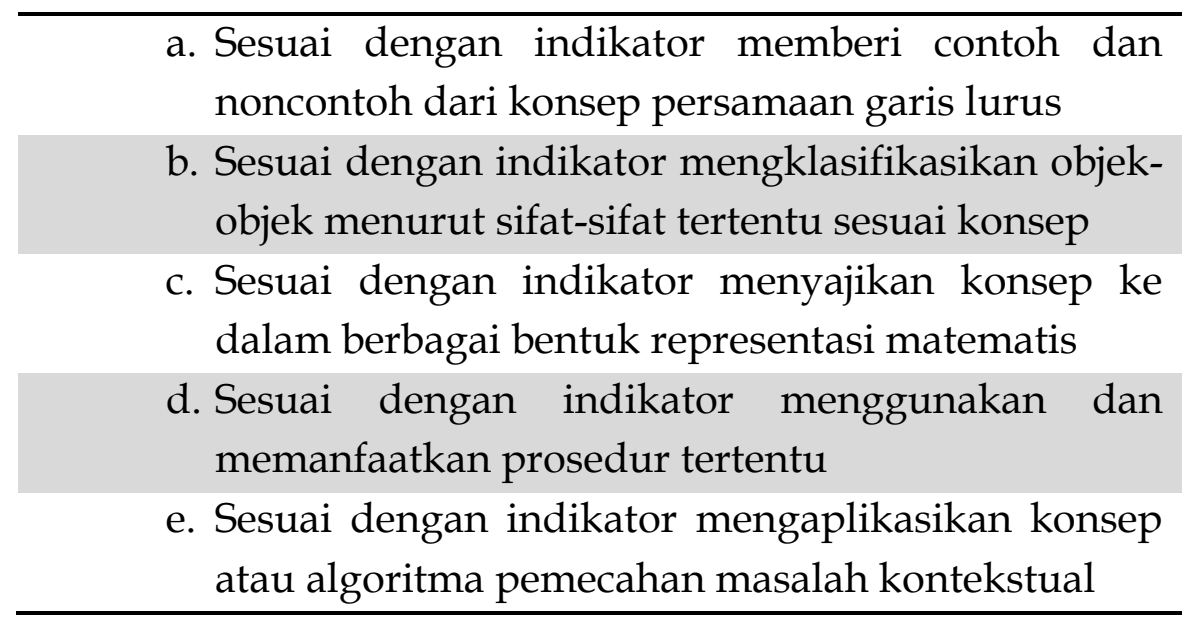

Untuk pedoman penskoran untuk tiap item sebagai berikut.

Tabel 4. Pedoman Penskoran Pengamatan Aktivitas Siswa

\begin{tabular}{lc}
\hline \multicolumn{1}{c}{ Aktivitas } & Nilai \\
\hline Menjawab Benar Putaran Pertama & 1 \\
Menjawab Benar Putaran Kedua & 0.75 \\
Menjawab Benar Putaran Ketiga & 0.50 \\
Menjawab Benar Putaran Keempat dst & 0.25 \\
\hline
\end{tabular}

Data hasil pengamatan aktivitas siswa dianalisis dengan langkahlangkah berikut:

Menjumlah skor setiap siswa pada lembar pengamatan aktivitas siswa Menghitung skor rata-rata siswa (Sr) dengan rumus:

$\mathrm{S}_{\mathrm{r}}=\frac{\mathrm{S}_{\mathrm{t}}}{\sum \text { butir }}$

$\mathrm{S}_{\mathrm{r}}=$ Skor rata-rata setiap siswa

$\mathrm{S}_{\mathrm{t}}=$ Skor total setiap siswa

$\sum$ butir $=$ Jumlah butir skor

Menjumlah $\mathrm{S}_{\mathrm{r}}$ semua siswa

Menghitung rata-rata untuk semua siswa $\left(\mathrm{S}_{\mathrm{m}}\right)$ dengan rumus:

$$
\begin{aligned}
& \mathrm{S}_{\mathrm{m}}=\frac{\sum S_{r}}{n} \\
& \mathrm{~S}_{\mathrm{m}}=\text { Skor rata-rata semua siswa } \\
& \sum S_{r}=\text { Jumlah skor rata-rata setiap siswa } \\
& n=\text { Jumlah siswa }
\end{aligned}
$$

Membuat kesimpulan dan hasil pengamatan aktivitas siswa dengan kriteria seperti pada tabel 5 . 
Tabel 5. Kriteria Media Pembelajaran terhadap Pemahaman Konsep

\begin{tabular}{ll}
\hline \multicolumn{1}{c}{ Kriteria } & \multicolumn{3}{c}{ Interpretasi } \\
\hline $\mathbf{0 , 7 5} \leq \mathbf{S}_{\mathbf{m}} \leq \mathbf{1 , 0 0}$ & $\begin{array}{l}\text { Media sangat baik untuk memfasilitasi kemampuan } \\
\text { pemahaman konsep }\end{array}$ \\
$\mathbf{0 , 5 0} \leq \mathbf{S}_{\mathbf{m}}$ & $\begin{array}{l}\text { Media baik untuk memfasilitasi kemampuan } \\
\text { pemahaman konsep }\end{array}$ \\
& $\begin{array}{l}\text { Media cukup baik untuk memfasilitasi pemahaman } \\
\text { konsep }\end{array}$ \\
$\mathbf{0 , 2 5} \leq \mathbf{S}_{\mathbf{m}}$ & $\begin{array}{l}\text { Media tidak baik untuk memfasilitasi pemahaman } \\
<\mathbf{0 , 5 0}\end{array}$ \\
$\mathbf{0} \leq \mathbf{S}_{\mathbf{m}}<\mathbf{0 , 2 5}$ & konsep
\end{tabular}

Diadopsi dari (Arikunto, 2011).

Sedangkan untuk data kualitatif dianalisis dengan menggunakan model interactive model, yang meliputi reduksi data (data reduction), penyajian data (data display), dan conclutions drowing/verifiying. Adapun alur teknik analisis sebagai berikut.

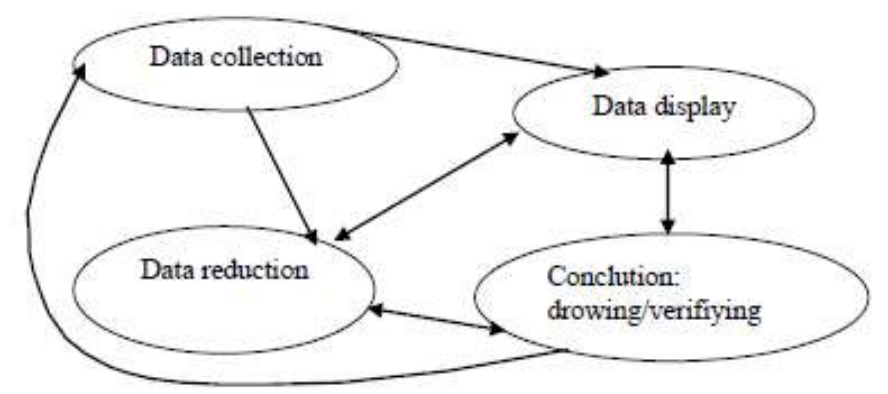

Gambar 1. Teknik Analisis Data (Interactive Model) (Spradley, 2007).

\section{HASIL PENELITIAN DAN PEMBAHASAN}

Media ADAMMATH adalah media dalam matematika berupa permainan sederhana yang membentuk bidang petak-petak semacam koordinat kartesius yang disertai soal-soal mengenai persamaan garis lurus dan terdapat petunjuk penggunaan untuk mempermudah siswa menggunakan media ini. Satu paket media ADAMMATH terdiri dari papan media $A D A M M A T H$, pion, nomor pion, kartu soal, lembar kunci jawaban dan petunjuk penggunaan. 


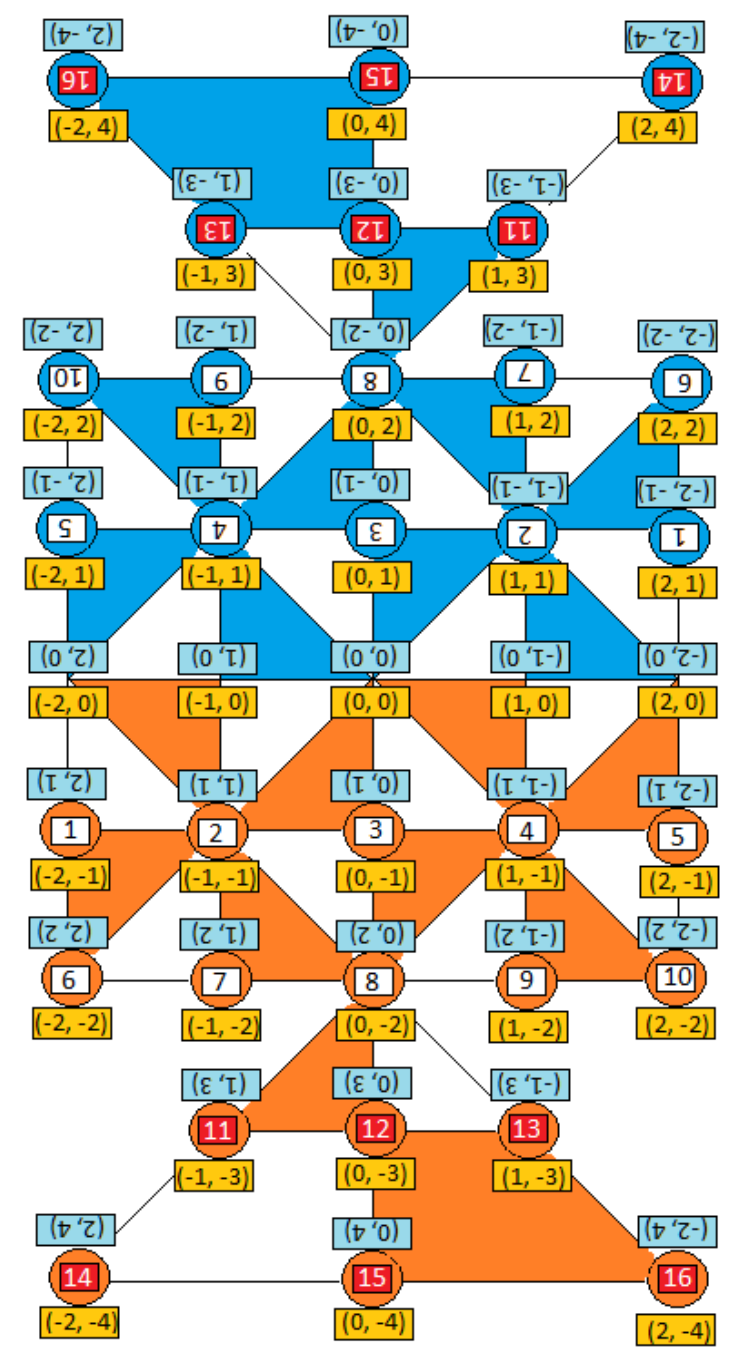

Gambar 2. Papan Lengkap Media ADAMMATH

Media ADAMMATH diujicobakan pada 28 siswa kelas VIII MTs Umar Zahid Perak. Hasil uji coba dan hasil analisis yang dilakukan dipaparkan sebagai berikut.

\section{a. Hasil angket respons siswa}

Keefektifan media ADAMMATH dapat dilihat dari hasil angket respons siswa. Angket respons siswa diberikan setelah siswa menggunakan media ADAMMATH. Data angket respons siswa ini berfungsi untuk mengetahui sejauh mana kualitas dan kuantitas serta hambatan yang dirasakan siswa selama mengikuti proses pembelajaran menggunakan media ADAMMATH terhadap kemampuan pemahaman konsep matematis siswa. 
Rekapitulasi data hasil angket respons siswa menunjukkan bahwa ratarata aspek skor respons siswa tertinggi sebesar 3,32 dan terendah sebesar 2,46. Analisis rata-rata aspek skor respons siswa tertinggi mengatakan bahwa media ADAMMATH membuat belajar matematika siswa menyenangkan sedangkan aspek skor siswa terendah mengatakan bahwa siswa merasa kebingungan dalam menggunakan media ADAMMATH. Berdasarkan data hasil angket respons siswa maka dapat disimpulkan bahwa secara keseluruhan, rata-rata skor respons siswa masuk dalam kategori baik sebesar $3,01(\mathrm{Sm} \geq 2,5)$. Berikut contoh komentar dan saran dari siswa:

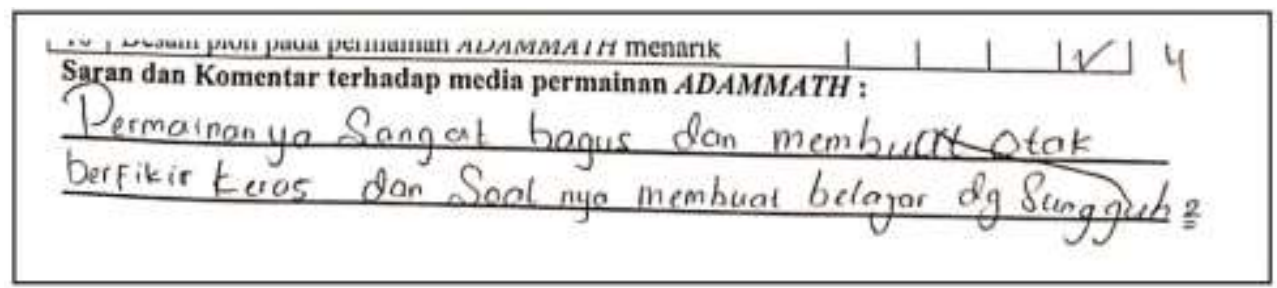

Gambar 3. Komentar Dari Siswa 1

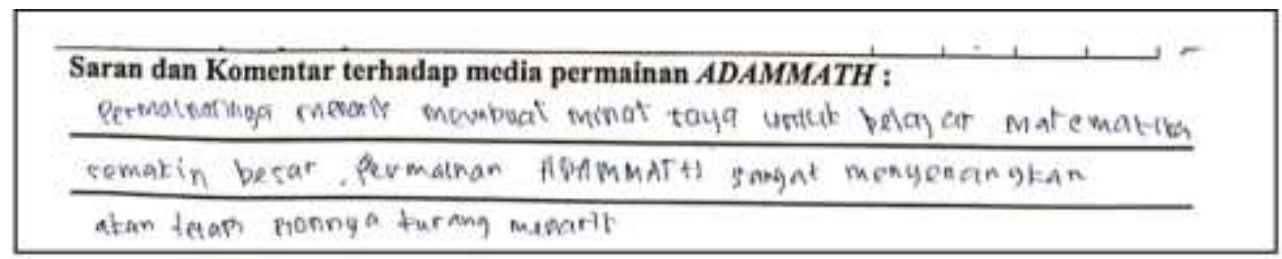

Gambar 4. Komentar Dari Siswa 2

Berdasarkan saran dan komentar siswa maka dapat disimpulkan bahwa media ADAMMATH sangat menyenangkan dan membuat siswa bersemangat dalam belajar matematika, pembelajaran matematika akan lebih seru apabila menggunakan media seperti media ADAMMATH tidak hanya dijelaskan oleh guru saja yang bias membuat siswa bosan. Media ADAMMATH mudah untuk dipahami, media ADAMMATH membuat otak berpikir keras dan soal-soalnya membuat siswa belajar matematika dengan sungguh-sungguh, media ADAMMATH memudahkan dalam memahami materi persamaan garis lurus, soal-soal dalam media ADAMMATH terlalu sulit, tampilan warna media $A D A M M A T H$ kurang menarik, dan pion dalam media ADAMMATH kurang menarik. Hal ini senada dengan pendapat Prastika \& Purnama (2013) mengatakan bahwa permainan DAM merupakan salah satu permainan yang dapat mendidik karena sangat baik untuk 
memfasilitasi pemahaman konsep. Bagi anak, belajar adalah bermain, bermain adalah belajar dan anak lebih suka suasana bebas tanpa ada tekanan, berinteraksi dengan teman, dan bermain (Simanjuntak, 2008).

b. Hasil lembar pengamatan aktivitas siswa

Keefektifan media ADAMMATH juga dapat dilihat dari hasil pengamatan aktivitas siswa. Lembar pengamatan aktivitas siswa diberikan pada saat siswa menggunakan media ADAMMATH. Data lembar pengamatan aktivitas siswa ini berfungsi untuk melihat kemampuan pemahaman konsep matematis siswa dalam menggunakan media ADAMMATH.

Berdasarkan rekapitulasi data hasil pengamatan aktivitas siswa untuk memfasilitasi kemampuan pemahaman konsep matematis siswa diperoleh hasil 0,62 $\left(S_{m} \geq 0,50\right)$. Hal ini menunjukkan bahwa siswa dapat menjalankan pion sesuai aturan, menentukan gradien dengan tepat, dan menjawab soal dari kartu soal dengan tepat.

Media ADAMMATH dapat menilai kemampuan pemahaman konsep matematis siswa yaitu dengan cara melihat hasil pekerjaan siswa. Salah satu hasil pekerjaan siswa sesuai dengan indikator pemahaman konsep memberi contoh dan non contoh persamaan garis lurus dan indikator menyajikan konsep persamaan garis lurus ke dalam berbagai bentuk representasi matematis sebagai berikut.

Soal sesuai indikator memberi contoh dan non contoh persamaan garis lurus

Buatlah satu persamaan garis lurus dengan gradien 6

Soal sesuai indikator menyajikan konsep persamaan garis lurus ke dalam berbagai representasi matematis

Perhatikan gambar berikut!

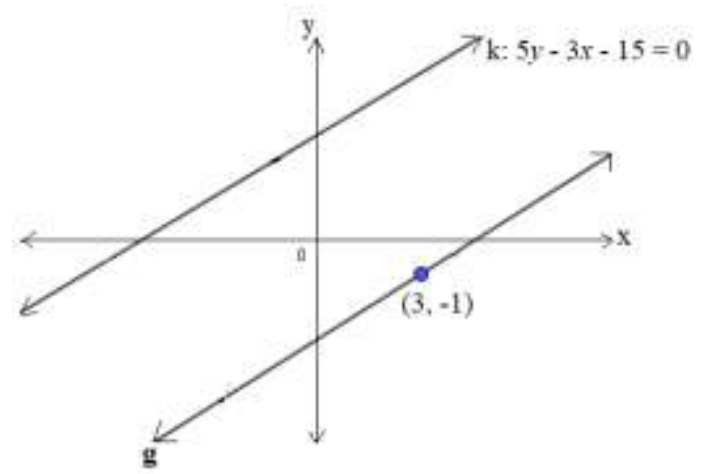

Tentukan persamaan garis $\mathrm{g}$ yang sejajar garis $\mathrm{k}$ dan melalui titik $(3,-1)$ !

Gambar 5. Salah Satu Soal Menyajikan Konsep ke dalam Berbagai Representasi Matematis 
Hasil pekerjaan siswa

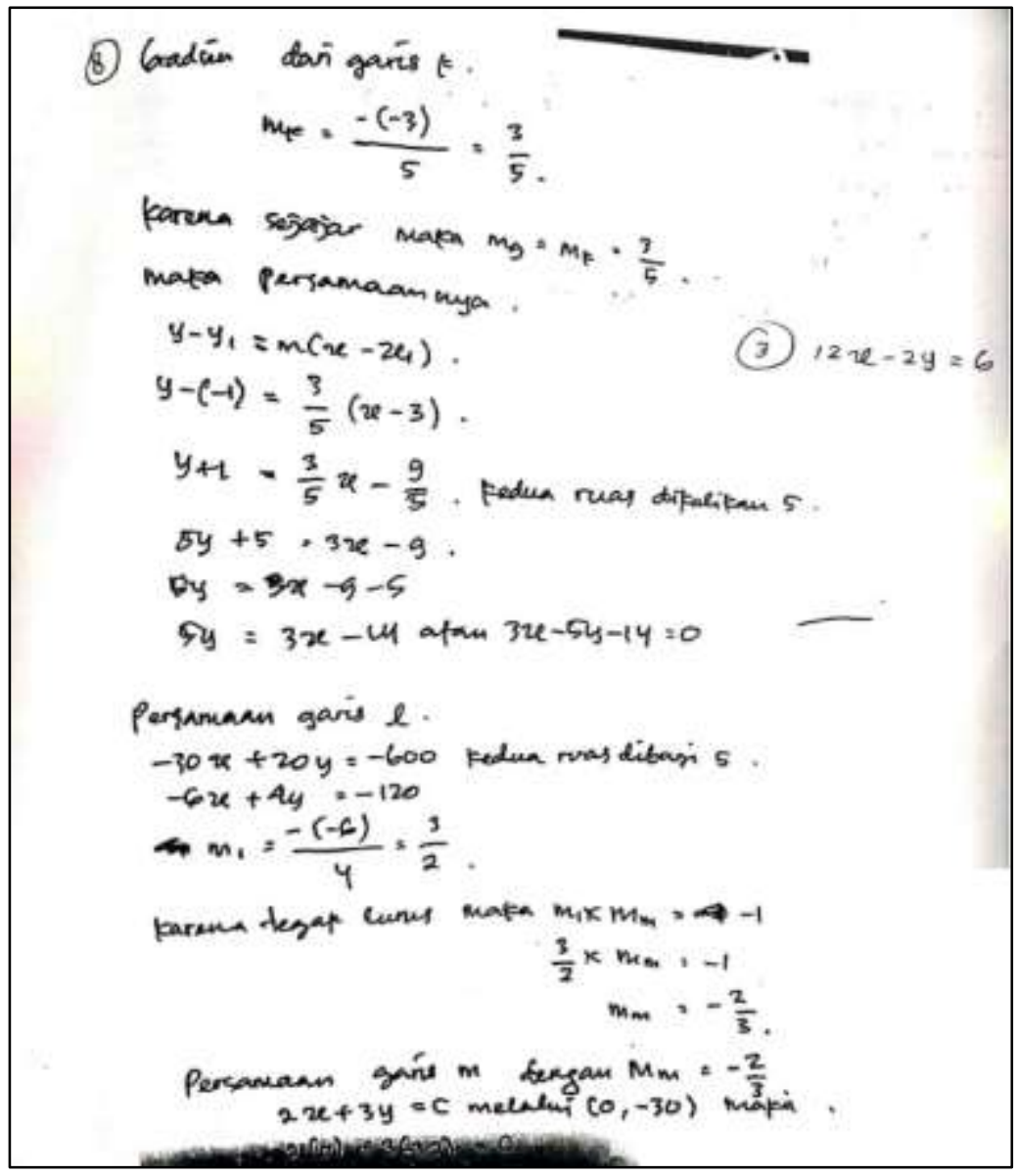

Gambar 5a. Hasil Pekerjaan Siswa

Indikator mengklasifikasikan hubungan dua persamaan garis lurus menurut sifat-sifat garis lurus sesuai dengan konsepnya

Soal sesuai indikator mengklasifikasikan hubungan dua persamaan garis lurus menurut sifat-sifat garis lurus sesuai dengan konsepnya Perhatikan persamaan-persamaan garis di bawah ini!

$$
\begin{aligned}
\text { i. } & x-2 y=3 \\
\text { ii. } & 2 x+y=4 \\
\text { iii. } & 2 x-4 y=5 \\
\text { iv. } & x+2 y=2
\end{aligned}
$$

Dari persamaan garis di atas, garis-garis yang saling sejajar adalah ...
a. (i) dan (ii)
b. (ii) dan (iii)
c. (i) dan (iii)
d. (ii) dan (iv) 
Hasil pekerjaan siswa

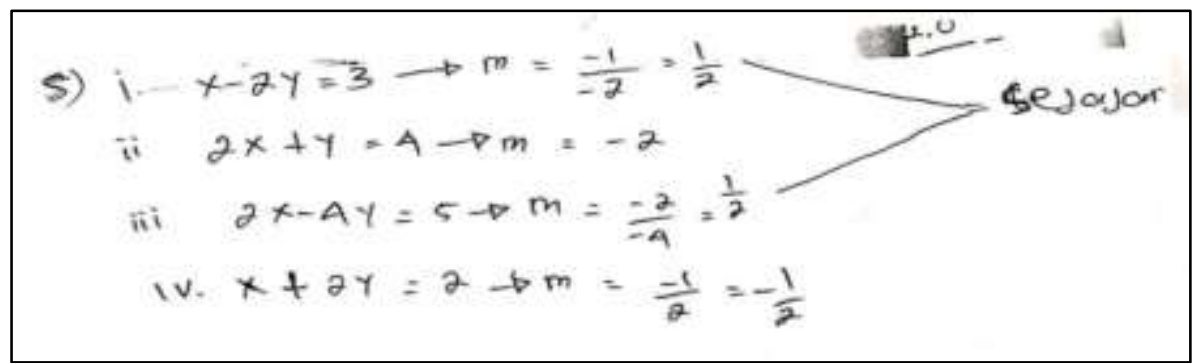

Gambar 5b. Hasil Pekerjaan Siswa

Indikator menggunakan dan memanfaatkan prosedur tertentu dalam menyelesaikan soal persamaan garis lurus

Soal sesuai indikator menggunakan dan memanfaatkan prosedur tertentu dalam menyelesaikan soal persamaan garis lurus

Persamaan garis melalui titik $(-2,5)$ dan sejajar garis $x-3 y+2=0$ adalah...

Hasil pekerjaan siswa

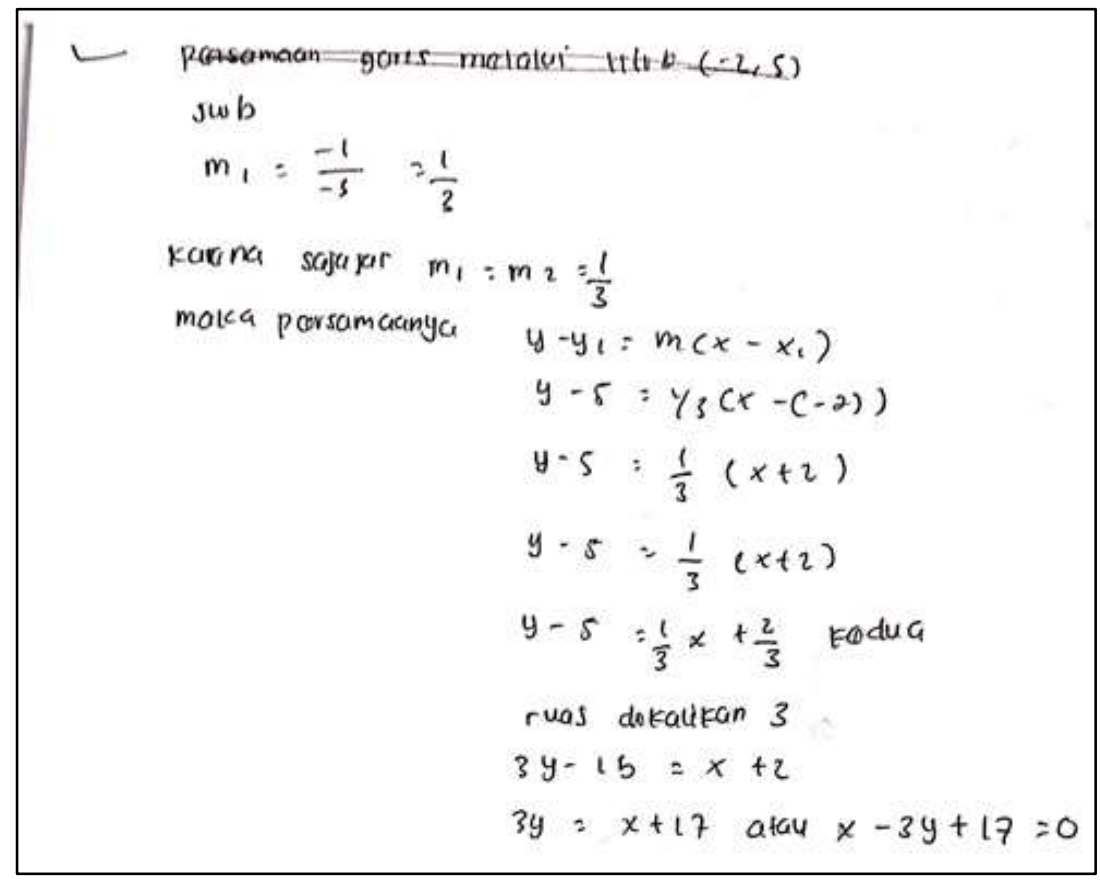

Gambar 5c. Hasil Pekerjaan Siswa

Indikator mengaplikasikan konsep atau algoritma persamaan garis lurus terhadap pemecahan masalah. 


\section{Soal sesuai indikator mengaplikasikan konsep atau algoritma persamaan garis lurus terhadap pemecahan masalah}

Diketahui titik $K(3,1), L(-1,-2)$, dan $M(-4, r)$. Jika garis yang melalui titik KL tegak lurus dengan garis yang melalui titik LM, maka nilai $r$ adalah ...

Hasil pekerjaan siswa

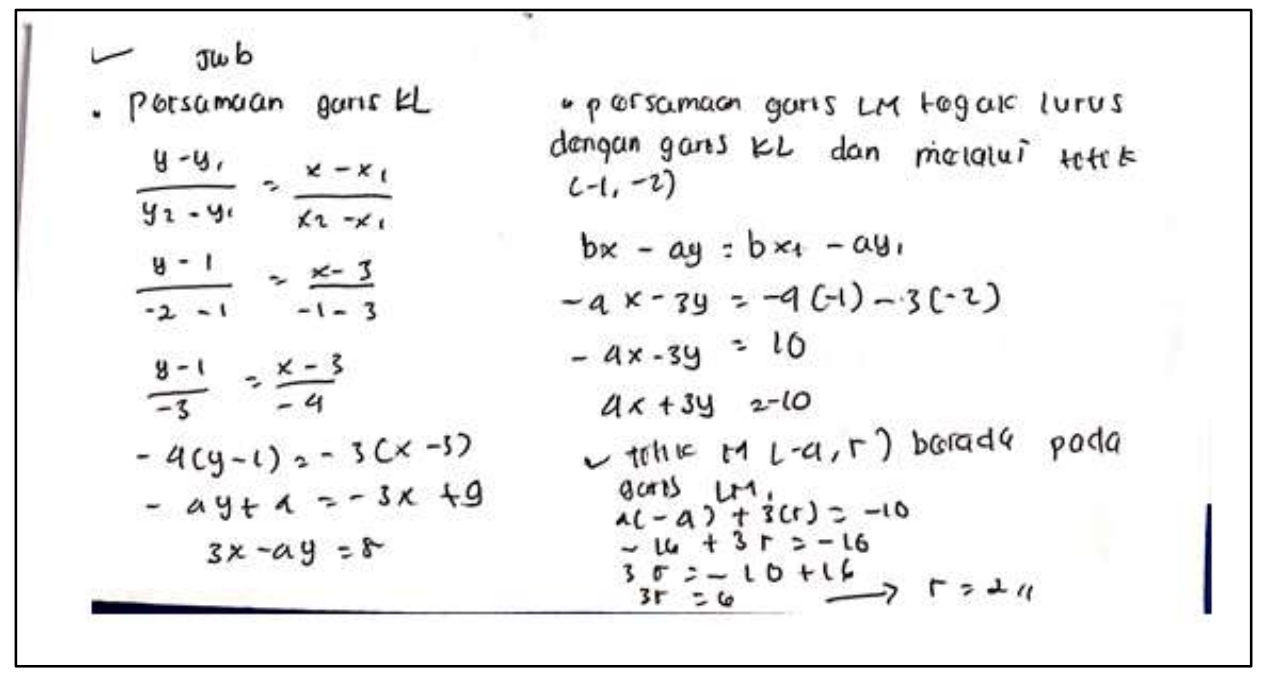

Gambar 5d. Hasil Pekerjaan Siswa

Media ADAMMATH (Aplikasi DAM Matematika) telah mampu membuat siswa lebih berpengalaman dalam menyelesaikan soal-soal persamaan garis lurus. Hal ini sejalan dengan pendapat Yohan dalam Asbiani (2016) bahwa guru perlu menggunakan media dalam pembelajaran karena penggunaan media dapat menghadirkan pengalaman yang konkret pada siswa dalam belajar.

Analisis keefektifan media ADAMMATH terhadap kemampuan pemahaman konsep matematis siswa pada materi persamaan garis lurus dilihat berdasarkan hasil angket respons siswa dan pengamatan aktivitas siswa untuk melatih kemampuan pemahaman konsep matematis siswa telah efektif digunakan untuk proses pembelajaran matematika.

\section{SIMPULAN}

Berdasarkan hasil pembahasan maka dapat disimpulkan bahwa media ADAMMATH (Aplikasi DAM Matematika) efektif terhadap kemampuan pemahaman konsep matematis siswa pada materi persamaan garis lurus. Hal ini dilihat dari hasil angket respons siswa yang memenuhi kategori baik yaitu 3,01 $\left(S_{m} \geq 2,5\right)$ dan lembar pengamatan aktivitas siswa untuk melihat 
kemampuan pemahaman konsep matematis siswa menggunakan media ADAMMATH memenuhi kriteria baik yaitu 0,62 $\left(S_{m} \geq 0,50\right)$ serta dapat dibuktikan dengan siswa merasa senang dan bersemangat untuk belajar matematika serta mampu merubah suasana belajar yang bebas tanpa ada tekanan dari guru karena siswa belajar sambil bermain yang membuat siswa lebih berpengalaman dalam menyelesaikan soal-soal pada materi persamaan garis lurus.

\section{DAFTAR PUSTAKA}

Arikunto, S. (2011). Dasar-dasar evaluasi pendidikan edisi revisi. Jakarta: PT Bumi Aksara.

Asbiani, A. I. (2016). Pengembangan media pembelajaran kartu HIMA (Hitung Matematika) untuk melatih kemampuan pemecahan masalah siswa kelas VII. Universitas Pesantren Tinggi Darul ‘Ulum.

Astuty, V. W. D. (2012). Penggunaan program geogebra dalam upaya mengatasi kesulitan belajar siswa kelas VIII E SMP N 1 Nanggulan Kulon Progo pokok bahasan grafik garis lurus pada pembelajaran remidial. Universitas Sanata Dharma.

Hardani, D. P. (2017). Pengaruh model TGT disertai permainan DAM terhadap hasil belajar siswa pada materi hidrokarbon. Jurnal Pendidikan Dan Pembelajaran Khatulistiwa, 06(09).

Kesumawati, N. (2008). Pemahaman konsep matematik dalam pembelajaran matematika. Prosiding Seminar Nasional Matematika Dan Pendidikan Matematika. Retrieved from https://eprints.uny.ac.id/6928/.

NCTM. (2000). Principles and standards for school mathematics. United States of Amerika: The National Council of Teachers of Mathematics, Inc.

OECD. (2015). PISA 2015 Draft mathematics framework. Columbia University.

Prasetyo, M. F., \& Prihatnani, E. (2018). Pengembangan permainan monomath pada materi persamaan garis lurus bagi siswa kelas VIII SMPN 10 Salatiga. MAJU: Jurnal Ilmiah Pendidikan Matematika, 05(01), 14-26.

Prastika, M. R., Purnama, B. E. \& S. (2013). Pembuatan game dam-daman menggunakan Java. IJNS: Indonesian Jurnal of Network and Security, 01(01).

Priangga, Y. S. (2017). Pengembangan media pembelajaran matematika berbasis aplikasi android untuk memfasilitasi kemampuan pemahaman konsep siswa SMP kelas VIII materi persamaan linier dua variabel. Universitas Islam Negeri Sunan Kalijaga.

Putra, A. P. (2016). Analisis kesulitan siswa dalam penyelesaian soal sifat-sifat gradien bab persamaan garis lurus pada siswa SMP PGRI Arjosari Kab. Pacitan. MAJU: Jurnal Ilmiah Pendidikan Matematika, 03(01), 44-67. 
Rahman, A. A. (2017). Pengembangan perangkat pembelajaran berbasis pendekatan realistik untuk meningkatkan kemampuan pemecahan masalah matematis siswa SMPN 3 Langsa. MAJU: Jurnal Ilmiah Pendidikan Matematika, 04(01), 26-37.

Rahmawati, D. (2017). Pengembangan lembar kerja siswa (LKS) berbasis mind mapping untuk memfasilitasi pemahaman konsep matematis. Universitas Pesantren Tinggi Darul ‘Ulum.

Simanjuntak, P. (2008). Pengaruh time budget pressure dan resiko kesalahan terhadap penurunan kualitas audit. Universitas Diponegoro Semarang.

Spradley, J. P. (2007). Metode etnografi. Yogyakarta: Tiara Kusuma.

Sudiono, E. (2017). Analisis kesalahan dalam menyelesaikan soal matematika materi persamaan garis lurus berdasarkan analisis newman. UNION: Jurnal Ilmiah Pendidikan Matematika, 05(03), 295-302.

Tabach, M., Arcavi, A. \& Hershkowitz, R. (2008). Transitions among different symbolic generalizations by algebra beginners in a computer intensive environment. Educational Studies in Mathematics, 69(1), 53-71. Retrieved from https://www.learntechlib.org/p/101711/

Tanjungsari, R. D., Soedjoko, E., \& M. (2012). Diagnosis kesulitan belajar matematika SMP pada materi persamaan garis lurus. Unnes Journal of Mathematics Education, 01(01). Retrieved from https://doi.org/10.15294 / ujme.v1i1.261.

TIMSS. (2011). TIMSS 2011 International Result In Mathematics. TIMSS \& PIRLS International Study Center.

Vitantri, C. A. (2017). Integrasi concise learning method dengan mind mapping pada pembelajaran matematika di perguruan tinggi. Beta: Jurnal Tadris Matematika, 10(01), 203-221.

Yamasari, Y. (2010). Pengembangan media pembelajaran matematika berbasis ICT yang berkualitas. Makalah Disajikan Pada Seminar Nasional Pascasarjana X ITS. Retrieved from http://www.salamsemangat.files. wordpress.com 